\title{
HPV: A Virus-Dinosaur Living Among Us?
}

Guest Editors

Adhemar Longatto-Filho, São Paulo/Braga/Barretos

Kari Syrjänen, Turku

11 figures, 8 in color, and 13 tables, 2019 
S. Karger

Medical and Scientific Publishers

Basel $\cdot$ Freiburg $\cdot$ Hartford $\cdot$ Oxford

Bangkok $\cdot$ Dubai $\cdot$ Kuala Lumpur .

Melbourne $\cdot$ Mexico City .

Moscow $\cdot$ New Delhi $\cdot$ Paris .

Shanghai $\cdot$ Tokyo
Disclaimer

The statements, opinions and data contained in this publication are solely those of the individual authors and contributors and not of the publisher and the editor(s). The appearance of advertisements in the journal is not a warranty, endorsement, or approval of the products or services advertised or of their effectiveness, quality or safety. The publisher and the editor(s) disclaim responsibility for any injury to persons or property resulting from any ideas, methods, instructions or products referred to in the content or advertisements.

Drug Dosage

The authors and the publisher have exerted every effort to ensure that drug selection and dosage set forth in this text are in accord with current recommendations and practice at the time of publication. However, in view of ongoing research, changes in government regulations, and the constant flow of information relating to drug therapy and drug reactions, the reader is urged to check the package insert for each drug for any change in indications and dosage and for added warnings and precautions. This is particularly important when the recommended agent is a new and/or infrequently employed drug.
All rights reserved.

No part of this publication may be translated into other languages, reproduced or utilized in any form or by any means, electronic or mechanical, including photocopying, recording microcopying, or by any information storage and retrieval system, without permission in writing from the publisher or in the case of photocopying, direct payment of a specified fee to the Copyright Clearance Center (see "General Information")

(C) Copyright 2019 by S. Karger AG,

P.O. Box, CH-4009 Basel (Switzerland)

Printed on acid-free and non-aging paper (ISO 9706)

ISBN 978-3-318-06518-3

e-ISBN 978-3-318-06519-0

\section{KARGER}




\section{Contents}

Preface

83 HPV: A Virus-Dinosaur Living among Us?

Longatto-Filho, A. (São Paulo/Braga/Barretos); Syrjänen, K. (Kaarina)

Reviews

85 Human Papillomavirus Research: Where Should We Place Our Bets? Cuschieri, K. (Edinburgh); Lorincz, A.T.; Nedjai, B. (London)

97 Adaptation of Alpha-Papillomavirus over Millennia de Oliveira, C.M. (Barretos)

100 Beta Human Papillomavirus and Associated Diseases Sichero, L. (São Paulo); Rollison, D.E.; Amorrortu, R.P. (Tampa, FL); Tommasino, M. (Lyon)

109 Human Papillomavirus and Genital Disease in Men: What We Have Learned from the HIM Study

Sichero, L. (São Paulo); Giuliano, A.R. (Tampa, FL); Villa, L.L. (São Paulo)

118 New Insights into the Role of Human Papillomavirus in Anal Cancer and Anal Wart Development

Albuquerque, A.; Medeiros, R. (Porto)

124 HPV in Head and Neck Carcinomas: Different HPV Profiles in Oropharyngeal Carcinomas - Why?

Syrjänen, S. (Turku); Syrjänen, K. (Helsinki/Barretos)

143 HPV Infections in Heterosexual Couples: Mechanisms and Covariates of Virus Transmission

Kero, K.; Rautava, J. (Turku)

148 From HPV Infection to Lesion Progression: The Role of HLA Alleles and Host Immunity

Paaso, A. (Turku); Jaakola, A. (Turku/Kotka); Syrjänen , S.; Louvanto, K. (Turku)

159 HPV Vaccine: Updates and Highlights

de Oliveira, C.M. (Barretos); Fregnani, J.H.T.G. (Barretos/São Paulo); Villa, L.L. (São Paulo)

169 Author Index / Subject Index 